\title{
PHENYLKETONURIA WITH NORMAL INTELLIGENCE AND GOWERS' MUSCULAR DYSTROPHY
}

\author{
BY \\ STEPHEN COATES, A. P. NORMAN and L. I. WOOLF
From the Institute of Child Health, University of London, and The Hospital for Sick Children, Great Ormond Street,
London
}

(RECEIVED FOR PUBLICATION FEBRUARY 5, 1957)

Phenylketonuria is a rare inborn error of metabolism, which is believed to be associated almost always with some degree of mental retardation. The great majority of those affected are idiots or imbeciles; any with an intelligence quotient over 65 are rare enough to merit reporting (e.g., Low, Armstrong and Carlisle, 1956). Gowers' peripheral muscular dystrophy is also a very unusual disease in children. The case reported here showed this extremely rare combination of Gowers' muscular dystrophy, phenylketonuria and an intelligence quotient of over 100 . It appeared important, therefore, to determine any metabolic or other differences between this case and other phenylketonurics in the hope of throwing more light on the disease process.

\section{Case History}

A.T. was the fourth child of a family of five, born on July 29, 1948, a full-term male infant, weighing $6 \mathrm{lb} .3 \mathrm{oz}$. His progress was normal at first, and he used his hands well as a baby, but did not walk until the age of 20 months. He played normally with toys.

In June, 1951, when he was almost 3 years old, his mother noticed that he was holding the right hand as if there were no power in that wrist. She then noticed that he could no longer hold a knife in the right hand nor open a door with it.

In January, 1952, he was found to have bilateral wrist drop, with hyperextension of the metacarpo-phalangeal joints. There was no obvious weakness elsewhere.

From the age of $3 \frac{1}{2}$ years to 5 years there was no great change in his condition, although he possibly became a little more clumsy, but during his fifth year his mother noticed that he seemed to slap his feet down when walking. He began to tire easily and had to be taken about in a wheeled chair. He also began to have attacks of abdominal distension and vomiting, lasting about 24 hours.

He was referred to The Hospital for Sick Children in the autumn of 1954 by Dr. I. H. Gosset. It was then noted that his face was somewhat expressionless and that he had a tendency to allow his mouth to gape open. He had a left internal squint. There was bilateral wrist drop with a flexion deformity of the fingers. There was wasting of the small muscles of both hands and the right forearm, bilateral pes cavus, and weakness of dorsiflexion of both feet with a tight Achilles tendon on both sides. The right deltoid and sternomastoid muscles as well as the right arm muscles were found to be weak. There were no sensory changes.

A diagnosis of muscular dystrophy of Gowers' type was made.

Electromyogram. Dr. A. T. Richardson reported as follows: The electromyogram showed normal intensityduration curves of the right tibialis anterior. There was no spontaneous activity and on volition there was a full interference pattern of short-duration and polyphasic motor unit potentials with a significant increase in high frequency component.

These findings are typical of a myopathic lesion. There was no evidence of denervation or of degeneration of the lower motor neurones.

Biopsy. Dr. Martin Bodian reported that a biopsy specimen of muscle showed considerable variation in the size of the individual muscle fibres; large and small fibres were scattered haphazardly throughout the muscle bundles. The large fibres sometimes showed degenerative changes and in a considerable number of them the cross striations were difficult to make out, because of homogenization and hyalinization of the sarcoplasm. Occasionally the fibres were definitely split. Degenerative changes were also seen in many of the small fibres. The sarcolemmal nuclei were enlarged and more pleomorphic than usual, but they did not appear to occupy a central position on the fibres (which is said to be a special feature of myotonic dystrophy). There was an increase of the interstitial fatty tissues and fatty replacement of some of the degenerate muscle fibres. The interstitial tissues contained numerous arterioles and venules and all the former were thick-walled and often showed hyaline changes in their walls. There was no inflammatory cell infiltration. Special techniques revealed that nerve fibres and motor end-plates were present, and that they showed no histological abnormalities. The appearances were those of a muscle dystrophy. 
Radiograph of Cervical Spine. No abnormality was seen beyond rather large rib elements to the seventh cervical vertebra.

\section{Chemical Investigations}

At the time this case was seen, we were looking for amino-aciduria in muscular dystrophy and in consequence the urine of this case was examined by paper chromatography.

The cerebrospinal fluid, blood and urine gave paper chromatogram patterns characteristic of phenylketonuria, with a very large excess of phenylalanine over the normal and with all other amino-acids normal. The concentration of phenylalanine in the cerebrospinal fluid was $30 \mu \mathrm{g}$. per ml., that in the fasting blood serum was $50 \mu \mathrm{g}$. per ml., and in the post-prandial blood serum $180 \mu \mathrm{g}$. per $\mathrm{ml}$. These values were estimated from the paper chromatograms and the accuracy of these figures is only $\pm 25 \%$.

Several 24-hour specimens of urine were examined; the results are given in Table 1. Phenylpyruvic acid was estimated by the method of Berry and Woolf (1952), phenylalanine, phenyllactic acid and phenylacetylglutamine by modifications (Woolf, in preparation) of the Kapeller-Adler (1934) method and the phenolic acids by a modified Millon's reaction (Berry and Woolf, 1952; Woolf, in preparation).

TABle 1.

EXCRETION WHILE ON A NORMAL DIET (FIVE SPECIMENS)

\begin{tabular}{|c|c|c|}
\hline Substance & & $\begin{array}{c}\text { Range } \\
\text { (mg. per } 24 \text { hours) }\end{array}$ \\
\hline $\begin{array}{l}\text { Phenylpyruvic acid .. } \\
\text { Phenyllactic acid } \ldots \\
\text { Phenylalanine } \\
\text { Phenylacetylglutamine } \\
\text { Phenolic acids (* total) } \\
\text { Phenolic keto-acids* }\end{array}$ & $\begin{array}{ll}\cdots & \cdots \\
\cdots & \cdots \\
\cdots & \cdots \\
\cdots & \cdots \\
\cdots & \cdots\end{array}$ & $\begin{array}{r}142-207 \\
98-168 \\
128-160 \\
385-690 \\
97-117 \\
65-90\end{array}$ \\
\hline
\end{tabular}

* As tyrosine.

An ethereal extract of the urine gave on paper chromatography and development with Ehrlich's reagent two purple spots with the $R$ values of indolyllactic and indolylacetic acid respectively. Similar spots were given by urine from other phenylketonurics but not from normals ( $c f$., Armstrong and Robinson, 1954); the concentrations of the abnormal indole derivatives in this child's urine were a little above the average though within the range found for phenylketonurics.

Every specimen of urine examined while the child was on a normal diet gave an unmistakable green colour with ferric chloride, but the intensity was less than that usually seen.

On treatment with a diet low in phenylalanine, just as in other phenylketonurics, phenylpyruvic acid, phenyllactic acid and abnormal indole and phenolic compounds vanished from the urine, while the concentrations of phenylalanine in the blood and urine dropped to normal, as did his excretion of phenylacetylglutamine.
The urine of the patient's father, mother, sister and three brothers showed no excess of phenylalanine on paper chromatograms.

The child's hair was medium brown. The percentage reflection of light at various wavelengths is given in Table 2. There was no appreciable further darkening during the three months that the child was fed on a diet low in phenylalanine ( $c f$. , Cowie and Penrose, 1951; Woolf, Griffiths and Moncrieff, 1955).

TABLE 2.

HAIR COLOUR

\begin{tabular}{|c|c|c|c|c|c|c|c|c|c|c|}
\hline $\begin{array}{l}\text { Wavelength }(\mathrm{m} \mu .) \\
\text { Reflectance }(\%)\end{array}$ & & $\begin{array}{c}700 \\
9\end{array}$ & $\begin{array}{c}670 \\
8\end{array}$ & $\begin{array}{c}600 \\
6\end{array}$ & $\begin{array}{l}580 \\
4 \cdot 5\end{array}$ & $\begin{array}{l}550 \\
4 \cdot 5\end{array}$ & $\begin{array}{l}520 \\
4 \cdot 5\end{array}$ & $\begin{array}{r}490 \\
4\end{array}$ & $\begin{array}{r}47 \\
4\end{array}$ & $\begin{array}{l}430 \\
3 \cdot 5\end{array}$ \\
\hline
\end{tabular}

\section{Psychological Investigations}

The tests demonstrated that A.T. was of average intelligence. This was true whether verbal or non-verbal tests were used. The slightly lower Wechsler scale measures were the result of the comparative failure in 'object assembly' where the muscular dystrophy had most effect; in any case a measure calculated from only three sub-tests cannot be as reliable as the Binet scale result.

TABLE 3.

INTELLIGENCE TEST RESULTS IN A.T.

\begin{tabular}{|c|c|c|c|c|c|}
\hline Date & \multicolumn{2}{|c|}{ Chronological Age } & \multicolumn{2}{|c|}{ Mental Age } & I.Q. \\
\hline \multicolumn{3}{|c|}{ 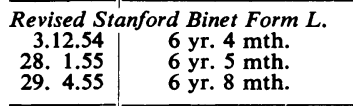 } & \multicolumn{2}{|c|}{$\begin{array}{l}6 \text { yr. } 6 \mathrm{mth} . \\
6 \text { yr. } 6 \mathrm{mth} . \\
7 \mathrm{yr} .0 \mathrm{mth} .\end{array}$} & $\begin{array}{l}103 \\
101 \\
105\end{array}$ \\
\hline Date & $\begin{array}{c}\text { Picture } \\
\text { Completion } \\
(\%)\end{array}$ & $\begin{array}{r}\text { Pic } \\
\text { Arran } \\
\text { (\% }\end{array}$ & nt & $\begin{array}{l}\text { Object } \\
\text { Assembly } \\
(\%)\end{array}$ & $\begin{array}{l}\text { Perform- } \\
\text { ance Scale } \\
\text { I.Q. }\end{array}$ \\
\hline \begin{tabular}{r|} 
Wechsler \\
912.54 \\
29.4 .55
\end{tabular} & $\begin{array}{c}\text { Intelligence Scal } \\
50 \\
65\end{array}$ & le for & $n$ & $\begin{array}{l}30 \\
30\end{array}$ & $\begin{array}{l}87 \\
93\end{array}$ \\
\hline
\end{tabular}

\begin{tabular}{|c|c|c|c|c|c|c|}
\hline Date & Set $A$ & Set $\mathbf{A}_{\mathbf{B}}$ & Set B & Score & Grade & $\begin{array}{c}\text { Percentile } \\
\text { Rank }\end{array}$ \\
\hline $\begin{array}{r}\text { Progressi } \\
3.12 .54 \\
29.4 .55\end{array}$ & $\begin{array}{c}\text { Matri } \\
7 \\
10\end{array}$ & $\begin{array}{c}(1947) \\
4 \\
2\end{array}$ & $\begin{array}{l}5 \\
2\end{array}$ & $\begin{array}{l}16 \\
14\end{array}$ & $\begin{array}{l}\text { III }+ \\
\text { III }-\end{array}$ & $\begin{array}{l}50 \\
26\end{array}$ \\
\hline
\end{tabular}

\begin{tabular}{|c|c|c|c|}
\hline Date & $\begin{array}{c}\text { First Trial } \\
\text { (sec.) }\end{array}$ & $\begin{array}{l}\text { Second Trial } \\
\text { (sec.) }\end{array}$ & $\begin{array}{c}\text { Third Trial } \\
\text { (sec.) }\end{array}$ \\
\hline $\begin{array}{c}\text { Seguin Fo } \\
23.1 .55 \\
29.4 .55\end{array}$ & $\begin{array}{r}\text { Board } \\
65 \\
45\end{array}$ & $\begin{array}{l}51 \\
37\end{array}$ & $\begin{array}{l}53 \\
28\end{array}$ \\
\hline
\end{tabular}

Retesting was carried out (Table 3) to measure the effect of three months on a phenylalanine-restricted diet. There were no significant differences in intelligence test measure. On retesting, the matrices test was given last of four tests, and A.T. was clearly very tired, and gave an inconsistent score pattern; this result is not reliable and does not invalidate the earlier result. 
The Seguin form board was given to measure manual dexterity, the muscular dystrophy making it, of course, valueless as a test of intelligence. The time was almost halved after three months of dietary treatment, which may be significant. It may, however, reflect the results of practice in using his hands.

A.T.'s eldest brother obtained a grammar school scholarship. It, therefore, seemed possible that A.T.'s score might be below the family average. All the family except the baby sister were therefore tested (Table 4).

TABLE 4.

RESULTS OF INTELLIGENCE TESTS ON A.T'S FAMILY

\begin{tabular}{|c|c|c|c|c|}
\hline & $\begin{array}{c}\text { Chrono- } \\
\text { logical } \\
\text { Age }\end{array}$ & $\begin{array}{r}\text { Verbal } \\
\text { I.Q. }\end{array}$ & $\begin{array}{c}\text { Performance } \\
\text { I.Q. }\end{array}$ & $\begin{array}{c}\text { Full Scale } \\
\text { I.Q. }\end{array}$ \\
\hline $\begin{array}{r}\text { Wechsler Be } \\
\text { Father... } \\
\text { Mother.. }\end{array}$ & $\begin{array}{c}\text { levue Scale } \\
34 \text { yr. } \\
35 \text { yr. }\end{array}$ & Form $L \begin{array}{r}104 \\
126\end{array}$ & $\begin{array}{l}112 \\
119\end{array}$ & $\begin{array}{l}109 \\
125\end{array}$ \\
\hline
\end{tabular}

\begin{tabular}{|c|c|c|c|}
\hline Sib & Chronological Age & Mental Age & I.Q. \\
\hline $\begin{array}{l}\text { Revised } \\
\text { G.T. } \\
\text { P.T. } \\
\text { R.T. }\end{array}$ & \begin{tabular}{|} 
Stanford Binet Form L \\
11 yr. 66 mth. \\
9 yr. 11 mth. \\
7 yr. 9 mth.
\end{tabular} & $\begin{array}{r}16 \text { yr. } 9 \text { mth. } \\
10 \text { yr. } 6 \text { mth. } \\
8 \text { yr. } 10 \text { mth. }\end{array}$ & $\begin{array}{l}142 \\
106 \\
114\end{array}$ \\
\hline
\end{tabular}

The father's performance scale I.Q. of 112, equivalent to a Binet I.Q. of 117 , is probably more reliable, from objective evidence, than the verbal measure of 104 . P.T.'s score is probably an underestimate; he was a disturbed boy who after a great deal of ill health was attending an open-air school; the supposition that this may have reduced the measure is supported objectively by the score pattern. His innate I.Q. was probably 116 . A.T., therefore, measured about 10 I.Q. points below the next lowest member of his family, or 18 I.Q. points below the family average in Binet terms.

\section{Discussion}

This is the only known untreated case of phenylketonuria with an intelligence rating of over 100 . Only one other case has been reported with an I.Q. close to this figure (average score of 94 on four intelligence tests, Cowie, 1951). A handful of cases have intelligence quotients ranging from 60 to 90 , but in the majority the I.Q. is less than 30 .

The distribution of intelligence among phenylketonurics is shown in Fig. 1 (Penrose, 1951). The mean intelligence quotient is 23 and the standard deviation \pm 14 , but the curve is very markedly skewed. Moreover, the data are drawn almost exclusively from patients in institutions and their relatives, which must result in the exclusion of some of the higher grade phenylketonurics. That the number so excluded is not very large is shown by the finding by Vulliamy and Woolf (unpublished) of only one case during a search for high-grade phenylketonurics among 2,200 educationally subnormal children of I.Q. 50 to 70 ( $c f$., Larson, 1956). In these circumstances it is difficult to do more than guess at the proportion of phenylketonurics with intelligence in the normal range, but it seems unlikely to be higher than $0.1 \%$.

The theory that the mental deficiency in phenylketonurics is due to an intoxication by phenylalanine or one of its abnormal metabolites (Woolf and Vulliamy, 1951) has been confirmed by the success of a low-phenylalanine diet in preventing or partially reversing the mental deficiency (Woolf et al., 1955; Bickel, Gerrard and Hickmans, 1953; Armstrong and Tyler, 1955 ; Braude, 1956 ; Horner and Streamer, 1956).

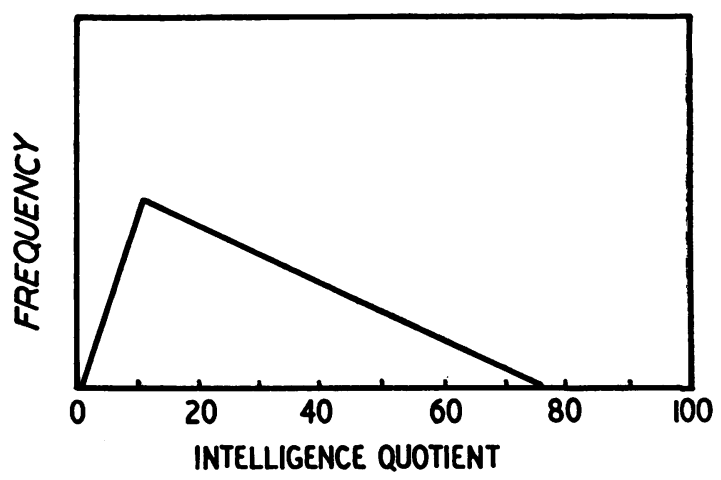

FIG. 1.-Diagram illustrating the distribution of intelligence quotient among phenylketonurics (from Penrose, 1951).

In the case reported here (as shown above) the patient's test scores are rather lower than might have been expected from the family results, and it is possible that some mental deterioration has occurred. The deterioration is, however, minimal, and quite negligible compared with that undergone by most phenylketonurics.

The chemical investigations revealed no qualitative differences between this patient and other phenylketonurics. The phenylalanine concentration in the C.S.F. was high, as in other phenylketonurics, indicating no difference in permeability of the blood-brain barrier that might account for the lesser mental damage. The phenylalanine concentration in post-prandial blood and the urinary excretion of phenylalanine were not markedly different from those found in other phenylketonurics of this agegroup. The urinary excretion of phenylacetylglutamine was variable but within the range found for other phenylketonurics. Indolyllactic and indolyl- 
acetic acids were present in the urine in concentrations which were no lower than those found in other phenylketonurics (Armstrong and Robinson, 1954), and very much higher than in normal individuals; this was also true of the ketonic and non-ketonic phenolic acids (Berry and Woolf, 1952).

The daily excretion of phenylpyruvic acid was only about one-quarter to one-seventh of that found in other phenylketonurics, and the excretion of phenyllactic acid was also rather lower. It is noteworthy that another case of phenylketonuria with high intelligence also excreted less than the average amount of phenylpyruvic acid (Cowie, 1951), while Følling (private communication, cf. Følling, Mohr and Ruud, 1945) found a low and intermittent excretion of this acid in some phenylketonurics who were intelligent enough to attend ordinary schools though not to do well there.

The medium brown hair colour in this patient, and the almost black hair in the case described by Cowie (1951), contrast sharply with the grey-blond hair so often found in phenylketonurics. Dancis and Balis (1955) ascribed this pale hair to an inhibition of melanin formation by a high concentration of phenylalanine, but other factors may also be active in vivo. The correlation of normal hair colour with normal intelligence in these two cases can hardly be coincidence; it suggests either a lower concentration of some inhibiting substance or a greater resistance to inhibition of the chemical reactions needed for melanin formation and for the transmission of neural impulses.

The idea is inescapable that there is some connexion between the higher intelligence and the lower excretion of phenyllactic acid and phenylpyruvic acid. Low et al. (1956) suggest that in some highgrade cases of phenylketonuria the metabolic block is only partial and some phenylalanine is converted to tyrosine. This becomes more acceptable if one adopts Pauling's (1955) idea of a 'molecular disease' as applied to phenylketonuria by Knox (1956). According to this view, the mutant gene for phenylketonuria is incapable of carrying out an essential stage in the synthesis of the enzyme phenylalanine hydroxylase, and some other protein, which is enzymatically inactive, is produced instead. Phenylketonuria results when an individual is homozygous for this mutant gene. It is, however, possible that another allele at the same locus synthesizes a protein with appreciable, though greatly reduced, enzyme activity. If this were the case it could account for the biochemical results found in some high-grade phenylketonurics.

An alternative possibility is that the renal tubular reabsorption of phenylalanine is, for some reason, relatively inefficient in certain cases. This would result in a lowering of the concentrations of phenylalanine and its abnormal metabolites in the blood and tissues, and so reduce the degree of intoxication. The low concentration of phenylalanine in the blood of A.T. after an overnight fast lends some support to this hypothesis. Følling et al. (1944) found that phenylpyruvic acid was absent from some early morning specimens of urine from an educable phenylketonuric; this would also fit in with the above hypothesis since phenylpyruvic acid is not excreted when the blood phenylalanine concentration falls below a certain level. A low kidney threshold for phenylalanine would have to operate from earliest infancy if it were materially to reduce the degree of mental deficiency. It should be possible to test these alternative hypotheses using recently devised techniques.

The non-specific hydroxylation mechanism (Dalgliesh, 1954, 1955; Brodie, Axelrod, Shore and Udenfriend, 1954; Udenfriend, Clark, Axelrod and Brodie, 1954; Udenfriend and Bessman, 1953) cannot account for the low excretion of phenylpyruvic and phenyllactic acids in this case. Both ortho- and para-hydroxy derivatives are produced in equivalent amounts by this mechanism and the former are excreted. The excretion of such phenolic compounds in this case was no higher than that found in other phenylketonurics.

Treatment for three months with a diet low in phenylalanine did not cause any clinically detectable improvement in the muscular dystrophy. There was no significant increase in intelligence, though this was not unexpected after so short a course of treatment. It did not seem justifiable to prolong treatment with an artificial diet in a child of this age and mental development. The absence of any further darkening of the hair while on this diet supports the suggestion that melanin formation was not interfered with in this patient.

No connexion can be traced between muscular dystrophy and phenylketonuria. Other phenylketonurics show no clinical evidence of muscular dystrophy and their electromyograms are normal (Richardson, private communication). It is improbable that a tendency towards muscular dystrophy on the part of phenylketonurics should become overt in the one case whose mentality is hardly affected. Ten other cases of muscular dystrophy have been examined and found to excrete no phenylpyruvic acid or excess of phenylalanine (Woolf, unpublished). Moreover, there are no reports in the literature of muscular dystrophy associated with phenylketonuria. We conclude that this is a chance combination of the two conditions. 


\section{Summary}

A case of phenylketonuria with an intelligence quotient of 103 and with peripheral muscular dystrophy is described. The patient excreted less phenylpyruvic and phenyllactic acids than most phenylketonurics. The correlation of mentality and biochemistry is discussed.

\section{Addendum}

This child was seen again in May, 1957. The serum 5-hydroxytryptamine was estimated by Dr. Stacey, and found to be $165 \mathrm{~m} . \mu \mathrm{g}$. per ml., which is well within the normal range, and far more than that found in most phenylketonurics (Pare, Sandler and Stacey, 1957).

His intelligence quotient was determined again, using the same battery of tests as before, and it was found to have fallen as follows: Revised Stanford-Binet I.Q., 89; progressive matrices, 1947, percentile rank: 10 ; Wechsler intelligence scale for children, performance I.Q., 83. The consistent direction of these changes makes them more probably significant. Thus, over a period of two years and one month the child's I.Q had fallen by an average of 18 points, suggesting deterioration. In view of this and his mother's feeling that he had been better while on a low phenylalanine diet, this diet has once more been instituted.

We are grateful to Dr. A. T. Richardson for the electromyographic reports on A.T. and on other phenylketonurics, and to Dr. Martin Bodian for examining the muscle biopsy specimen. We are grateful also to Mrs. V. Cowie who determined the hair reflectance at different wavelengths and to Dr. I. H. Gossett for obtaining specimens of urine from the patient's family. We wish to thank the patient's family for submitting to intelligence tests, the Northampton Education Authority for their cooperation, the dietitian and nursing staff at Great Ormond Street and Tadworth Court for feeding the special diet and collecting specimens. Professor L. S. Penrose kindly permitted us to use Fig. 1. The Research Committee of The Hospital for Sick Children awarded one of us (L.I.W.) a research fellowship and financed the investigation.

\section{REFERENCES}

Armstrong, M. D. and Robinson, K. S. (1954). Arch. Biochem. Biophys., 52, 287.

- and Tyler, F. H. (1955). J. clin. Invest., 34, 565.

Berry, J. P. and Woolf, L. I. (1952). Nature (Lond.), 169, 202.

Bickel, H., Gerrard, J. and Hickmans, E. M. (1953). Lancet, $2,812$.

Braude, H. (1956). S. Afr. med. J., 30, 83.

Brodie, B. B., Axelrod, J., Shore, P. A. and Udenfriend, S. (1954). J. biol.' Chem., 208, 741.

Cowie, V. A. (1951). Lancet, 1, 272.

and Penrose, L. S. (1951). Ann. Eugen. (Camb.), 15, 297.

Dalgliesh, C. E. (1954). Biochem. J., 58, Proc. p. xlv.

(1955). Arch. Biochem. Biophys., 58, 214.

Dancis, J. and Balis, M. E. (1955). Pediatrics, 15, 63.

Følling, A., Mohr, O. L. and Ruud, L. (1955). Skr. norske Vidensk.Akad., I. Mat.-nat. Kl. 1944, No. 13.

Horner, F. A. and Streamer, C. W. (1956). J. Amer. med. Ass., 161, 1628.

Kapeller-Adiler, R. (1934). Biochem. Z., 271, 206.

Knox, W. E. (1956). Bull. Tufts-New Engl. med. Cent., $2,1$.

Larson, C. A. (1956). In Gedda Novant' anni delle Leggi Mendeliane, p. 311. Rome.

Low, N. L., Armstrong, M. D. and Carlisle, J. W. (1956). Lancet, 2, 917 .

Pare, C. M. B., Sandler, M. and Stacey, R. S. (1957). Lancet, 1, 551.

Pauling, L. (1955). Harvey Lect. (1953-1954), 49, 216.

Penrose, L. S. (1951). Ann. Eugen. (Camb.), 16, 134.

Udenfriend, S. and Bessman, S. P. (1953). J. biol. Chem., 203, 961, Clark, C. T., Axelrod, J. and Brodie, B. B. (1954). Ibid., 208, 734 .

Woolf, L. I. and Vulliamy, D. G. (1951). Archives of Disease in Childhood, 26, 487.

_-, Griffiths, R. and Moncrieff, A. (1955). Brit. med. J., 1, 57. 